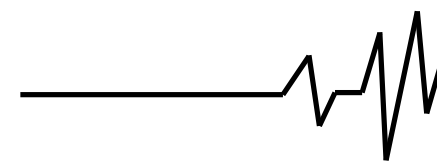

Степаненко С. П. K.T.H., C.H.C.

Національний науковий центр «lнституm механізації та електрифікації сільського господарства»

Котов Б. І. д.Т.н., професор

Подільський державний аграрно-технічний університет

\section{Stepanenko S.}

\section{National Research Center "Institute of Mechanization and Electrification of Agriculture"}

Kotov B.

\section{Podolsk State Agrarian Technical University}

MATЕМАТИЧНЕ МОДЕЛЮВАННЯ ПРОЦЕСІВ ПОДІЛУ КОМПОНЕНТІВ ЗЕРНОВОГО МАТЕРІАЛУ В КОМБІНОВАНОМУ ВІБРАЦІЙНО-
ПОВІТРЯНОМУ СЕПАРАТОРІ

Розробка математичної моделі i розрахункових аналітичних залежностей для визначення траєкторій $i$ параметрів переміщення зерна у віброзрідженому шарі компонентів зернового матеріалу (КЗМ) при дії пульсуючого повітряного потоку.

Базуються на методах детермінованого математичного моделювання та теоретичної механіки на базі рівнянь руху матеріальної точки при змінній швидкості повітряного потоку та дії пульсуючого повітряного потоку. Теоретичні дослідження проведені з використанням методів математичного аналізу i моделювання. Результати досліджень оброблені із застосуванням елементів теорії ймовірності і математичної статистики з використанням пакетів прикладних програм, для визначення раціональних параметрів процесу застосовувалася методика статистичного планування експерименту.

Наведений математичний опис руху частинок КЗМ в комбінованому вібраційно-повітряному сепараторі при дії пульсуючого потоку повітря змінної швидкості. Отримано траєкторії руху частинок з різним розміром.

Отримане рівняння руху частки при дії пульсуючого потоку повітря дозволяє визначити залежність швидкості руху матеріалу у вібропневмозрідженому шарі зернового матеріалу від ряду фракторів: геометричних параметрів безпровального решета, кута подачі матеріалу, початкового кінематичного режиму матеріалу $\kappa_{0}$, показника кінематичного режиму безпровального решета $\kappa_{p}$, а також коефіцієнту вітрильності частки.

На основі теоретичних досліджень визначена можливість поділу частинок зернового матеріалу на фрракції за аеродинамічними властивостями при вібропневматичному завантаженні зерна в канал. Використання пульсуючого повітряного потоку, як розділяючого носія, $i$ з урахуванням відхиляючих сил, дозволило значно збільшити величину розщеплення траєкторій і критерій поділу зерна на фракції.

Ключові слова: вібраційно-повітряний сепаратор повітряний потік, змінна швидкість повітря, траєкторія, сила опору, пульсуючий потік повітря, коефіцієнт вітрильності. 


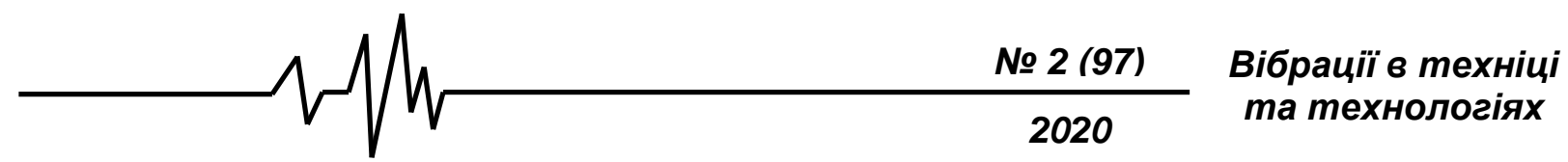

Постановка проблеми. В ринкових умовах виробництва зерна особливого значення набувають процеси механізації післязбиральної обробки зерна. Зерно матеріали після комбайнового збирання мають значну кількість домішок різного кількісного і якісного складу. Саме зерно являє собою поліфракційну за розміром, вологістю і біологічним складом масу.

Тому задача ефективного очищення і поділу КЗМ на фракції різного споживчого призначення (насіння, фураж, продовольче зерно) складає сутність проблеми підвищення технічної ефективності зерно сепараторів.

Фракціонування зернової маси повітряними потоками $є$ актуальним і перспективним напрямком розвитку технологій i машинних засобів первинної післязбиральної обробки зерна. При цьому використання повітряних потоків на початкових стадіях поділу забезпечує попереднє формування зернових потоків, які 3 мінімальними втратами і енергозатратами забезпечують отримання зерна продовольчих, насіннєвих і фуражних кондицій. Висока кореляція показника швидкості витання та технологічних властивостей компонентів зернових мас [7] дозволяє використовувати повітряну сепарацію на різних стадіях післязбиральної обробки зерна.

Але аналіз технічних характеристик сучасного устаткування та співставлення їх 3 вимогами попереднього фракціонування зібраного урожаю свідчить про відсутність можливості здійснювати очищення і поділ КЗМ застосуванням тільки одного типу робочих органів і необхідність створення комбінованих машинних технологій комплексної обробки зернового матеріалу.

Враховуючи, що пневмовібраційні робочі органи з повітряпроникненою поверхнею дозволяють ефективно розташовувати шар зернового матеріалу з видаленням сміттєвих домішок, доцільним $€$ використовувати в якості живильнодозуючого пристрою в пневматичних сепараторах.

Для визначення ефективності такого агрегатування робочих органів необхідно провести попереднє теоретичне дослідження, шляхом математичного моделювання процесів переміщення частинок КЗМ вібраційному шарі та повітряному каналі.

Незважаючи на значну кількість наукових праць і винаходів в цьому напрямку можливості подальшого вдосконалення пневмосепаруючих машин для зерно матеріалі повністю не вичерпані.

Аналіз останніх досліджень i публікації. В технічній літературі [1-3] і публікаціях [4-6] останніх років наведено достатньо даних, щодо опису принципів роботи та конструкцій машин для сепарації зернових матеріалів повітряними потоками, а також впливу діючих фракторів на їх ефективність [7-8] і методи розрахунків повітряних сепараторів [1, 8]. В роботах [4, 12] розглянуто процеси поділу насіння за аеродинамічними властивостями у каналі [4] та в зигзагоподібному каналі кільцевого перетину [9].

Серед способів підвищення ефективності роботи сепараторів різного типу слід відмітити наступні [4, 9, 11, 19-23]. Механічне вкидання насіння у вертикальний потік повітря висвітлено в роботі [1], в горизонтальному каналі [4], розташування при гравітаційному русі [12] і подача зерна пневмозрідженим шаром [13].

Особливим прийомом інтенсифрікації процесу поділу КЗМ за аеродинамічними властивостями $€$ використання пульсуючих потоків повітря $[13,14,15,16]$. Оцінка ефективності цього принципу сепарації засобами математичного моделювання наведена в роботах [13] і [14 - 16] пульсації потоку генеруються обертально-коливним збуджувачем. Але некоректне формулювання математичних моделей не дає можливості кількісного визначення ефективності дії такого способу інтенсифікації процесу поділу.

Вплив пульсації повітряного потоку в каналах зерносепараторів не досліджувалось.

Мета роботи Розробка математичної моделі і розрахункових аналітичних залежностей для визначення траєкторій i параметрів переміщення зерна у віброзрідженому шарі КЗМ при дії пульсуючого повітряного потоку.

\section{Результати}

досліджень. Технологічна схема об'єкта моделювання установки для фрракціонування КЗМ за аеродинамічними властивостями наведена на рис. 1. Схема силової взаємодії частинки із середовищем показано на рис. 2 і 3.

Завдання досліджень полягає у визначенні параметрів переміщення частинки (як матеріальної точки) в середовищі (коливному шарі зерна і потоку повітря). 


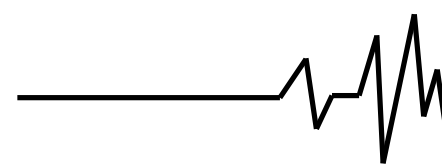

№ 2 (97)

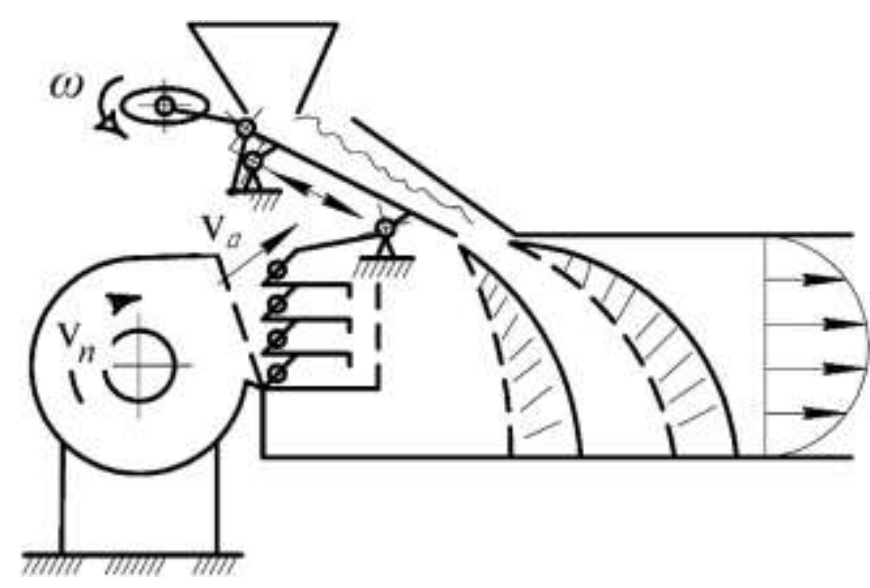

Рис.1. Технологічна схема установки для фракціонування КЗМ за аеродинамічними властивостями та питомою вагою

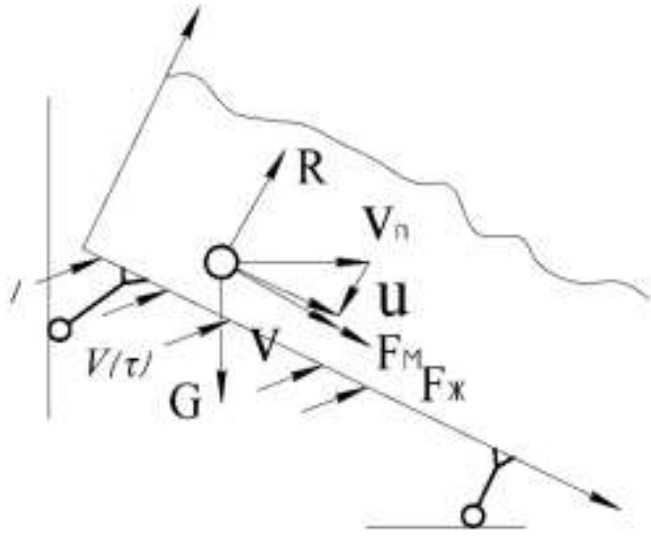

Рис.2. Схема силової взаємодії на вібруючому безпровальному решеті

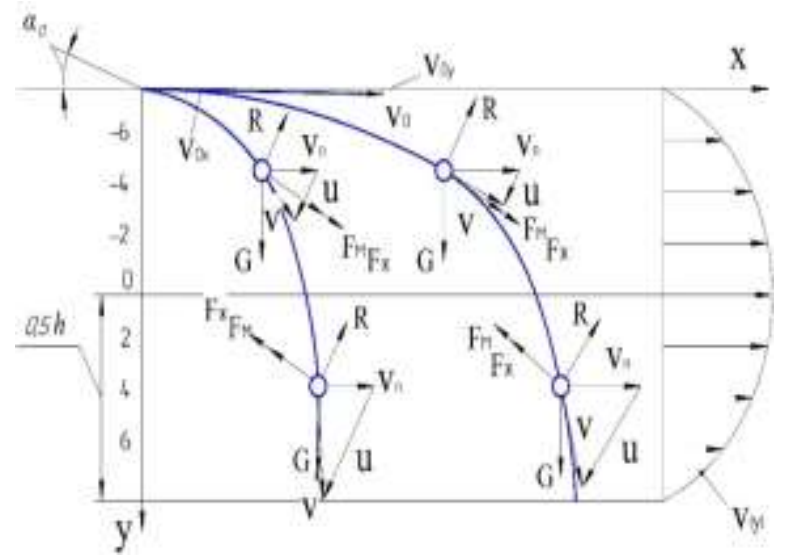

Рис.3. Схема силової взаємодії в горизонтальному потоці аеродинамічного сепаратора

Рух частинки в рухомому вібропневмозрідженому потоці зернового матеріалу розглядається, як рух тіла у в'язкій рідині (середовищі) з густиною ро.

Для опису такого процесу використане рівняння [13] яке у векторній формі має вигляд:

$$
m_{E} \cdot \overline{\dot{V}}=P+m_{0} \cdot(\Delta-1) \cdot \overline{\dot{U}}+F
$$

де $\overline{\dot{V}}$ - вектор швидкості частки відносно середовища;

$\overline{\dot{U}} \quad$ - абсолютна швидкість середовища в точці, що співпадає з центром тяжіння частки;

$$
m_{0}, m \text { - маса середовища в об'ємі }
$$
частки і маса проходової частинки (зернини); $m / m_{0}=\Delta ; m_{E}=m^{\prime}+m ; \Delta=m / m_{0}=\rho / \rho_{0}$

$m^{\prime}$ - «приєднана» маса частинки до середовища;

$\rho$ - густина частинки;

$\rho_{0}$ - густина середовища;

P - зовнішня сила, що діє на частинку в середовищі;

$$
\text { F - сила опору руху частинки. }
$$

Для встановлення характеристик процесу руху частинки складено рівняння її переміщення руху при таких спрощуючих припущеннях:

шар зернового матеріалу знаходиться в русі під дією силового поля, що створюється повітряним потоком і вібрацією опорної поверхні решета;

частинок однорідне;

$$
\text { поле швидкостей повітря i }
$$

швидкість коливань компонентів зернового матеріалу (КЗМ) співпадає із швидкістю коливань решета і носить гармонічний характер.

На частинку діють такі сили: тяжіння $G=m g$; інерції В переносному русі $P_{i}=m A \omega_{1}^{2} \sin (\omega t)$; 
$\ldots$

$R=m g \frac{\left(V_{a}(t)-V\right)^{2}}{V_{b}^{2}}$

опору

вздовж

траєкторії

переміщення частин $F=k_{\mu} \cdot V=k_{\mu}(\varepsilon) \cdot V$

у наведених співвідношеннях

позначено: $A, \omega_{1}$ - амплітуда і частота коливань решета; $V, V_{a}(t)$ - швидкість частинки і повітряного потоку; $V_{b}$ - швидкість витання

частинки у стисненому потоці; $k_{\mu}$ - коефріцієнт опору при прийнятті закону Стоксівського руху; $\varepsilon$ - порозність шару зернового матеріалу.

Вводячи переносну систему координат ХОУ, жорстко зв'язану з транспортуючою вібраційною площиною (при цьому вісь OX спрямована вздовж площини під кутом $\alpha$ до горизонту, а вісь ОУ нормально до неї) і проектуючи сили діючі на частинку у псевдозрідженому шарі отримаємо дифреренціальні рівняння руху частки:

$$
\begin{aligned}
& m \cdot \ddot{x}=\bar{m} g \sin \alpha \pm \bar{m} A_{1} \omega_{1}^{2} \cdot \cos \beta \cdot \sin \left(\omega_{1} t\right)-F_{X} \frac{\dot{x}}{\sqrt{\dot{x}^{2}+\dot{y}^{2}}}+m g \frac{\left(V_{a}-\dot{x}\right)^{2}}{V_{b}^{2}} \cos \gamma \\
& m \cdot \ddot{y}=\bar{m} g \cos \alpha \pm \bar{m} A_{1} \omega_{1}^{2} \cdot \sin \beta \cdot \sin \left(\omega_{1} t\right)-F_{Y} \frac{\dot{y}}{\sqrt{\dot{x}^{2}+\dot{y}^{2}}}+m g \frac{\left(V_{a}-\dot{y}\right)^{2}}{V_{b}^{2}} \sin \gamma
\end{aligned}
$$

$\beta$ - кут спряваності коливань;

$\gamma$ - кут нахилу напрямку потоку повітря до вісі OX.

При використанні пусьсуючого потоку повітря математично важко описати дискретноперіодичну зміну швидкості повітря, що подається крізь безпровальне решето, тому в першому наближенні можна прийняти зміну швидкості повітря в часі за гармонічним законом і описати рівнянням:

$$
V_{a}(t)=A_{2}\left(1+\sin \omega_{2} t\right)
$$

де $A_{2}$ - повна амплітуда коливань.
Швидкість переміщення частинки у пневмовіброзрідженому шарі набагато менша від швидкості повітря в шарі $\left(\dot{x}<<V_{a}, \dot{y}<<V_{a}\right)$, тому сила опору повітряному потоку буде визначатися співвідношенням:

$$
R=m g \frac{\left[A_{2} \cdot\left(1+\sin \omega_{2} t\right)\right]^{2}}{V_{b}^{2}}
$$

Параметри процесу руху частки в коливальному середовищі визначаються розв'язком рівнянь (2), (3) і (5) за допомогою обчислювальних методів з використанням ПК. Перепишемо рівняння у вигляді:

$$
\begin{aligned}
& \frac{d^{2} x(t)}{d t^{2}}+K_{X} \frac{d x(t)}{d t}=G_{X}+A_{1 X} \cdot \sin \left(\omega_{1} t\right)+A_{2 X} \cdot\left(1-\sin \left(\omega_{2} t\right)\right)^{2} \\
& \frac{d^{2} y(t)}{d t^{2}}+K_{Y} \frac{d y(t)}{d t}=G_{Y}+A_{1 Y} \cdot \sin \left(\omega_{1} t\right)+A_{2 Y} \cdot\left(1-\sin \left(\omega_{2} t\right)\right)^{2}
\end{aligned}
$$

$$
\begin{array}{cr}
\text { де } G_{X}=\frac{m-m_{0}}{m} g \sin \alpha G_{Y}=\frac{m-m_{0}}{m} g \cos \alpha ; & A_{2 Y}=K_{V} A_{2}^{2} \sin \gamma ; \\
A_{1 X}=\frac{m-m_{0}}{m} A_{1} \omega_{1}^{2} \cos \beta & \begin{array}{r}
K_{V} \text { - коефріцієнт вітрильності. } \\
\text { Початкові умови до системи рівня } \\
\text { запишемо у вигляді: }
\end{array} \\
A_{1 Y}=\frac{m-m_{0}}{m} A_{1} \omega_{1}^{2} \sin \beta ; A_{2 X}=K_{V} A_{2}^{2} \cos \gamma ; & \\
t=0 ; x=y=0 ; \dot{x}(0)=x_{o} ; \dot{y}(0)=y_{o} ; \dot{x}_{o}=v_{o x} ; \dot{y}_{o}=v_{o y}
\end{array}
$$$$
\text { Початкові умови до системи рівнянь (6) і (7) }
$$ 


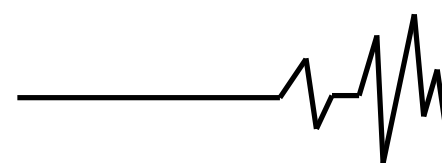

Величина ефективного коефіцієнту опору руху частки в середовищі може бути визначено 3 рівняння:

$$
K_{X, Y}=3 \cdot \pi \cdot v \cdot \rho_{a}(\varepsilon) \cdot d_{E} \cdot m^{-1}
$$

де $v$ - кінематичний коефіцієнт в'язкості середовища; середовища;

$$
\rho_{a}(\varepsilon)=\rho_{M}(1-\varepsilon) \text { - динамічна густина }
$$

$\rho_{M}$ - густина речовини;

$d_{E}$ - еквівалентний діаметр частинки.

Величина порозності віброзрідженого шару визначається за фрормулами [13]: при дії вібрацій

$$
\varepsilon=\varepsilon_{0} \cdot\left(1-e^{-k A_{1} \omega^{2}}\right)
$$

де $\varepsilon_{0}$ - порозність шару при відсутності вібрацій;

при дії вібрацій і повітряного потоку

$$
\varepsilon=1-A_{0} V_{a}^{2} \frac{a+\left(A \omega^{2}-g\right)^{-2}}{b+\left(A \omega^{2}-g\right)^{-2}}
$$

де $A_{0}, a, b$ - емпіричні коефіцієнти.

В прийнятій системі координат проекції руху часток $є$ розв'язком рівнянь (6-7) при початкових умовах. Результати розв'язку проведеного числовим методом в програмному середовищі Math CAD наведено на рис. 4 і рис. 5 у вигляді траєкторій руху часток 3 різними значеннями, якими характеризуються аеродинамічні властивості окремих зернин (вага, розмір).

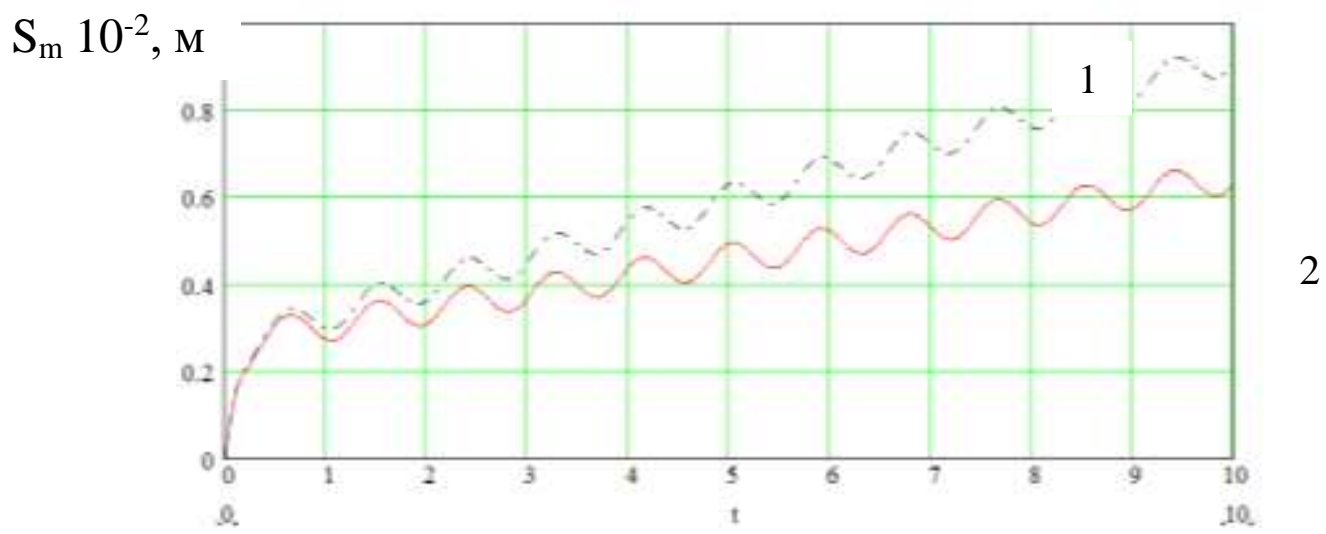

Рис.4. Зміна переміщення частки в шарі зерна при сталому потоці повітря. $\quad t, c$ 1 - $m=4,2 \cdot 10^{-6}$ кг; 2 - $m=2,4 \cdot 10^{-6}$ кг;

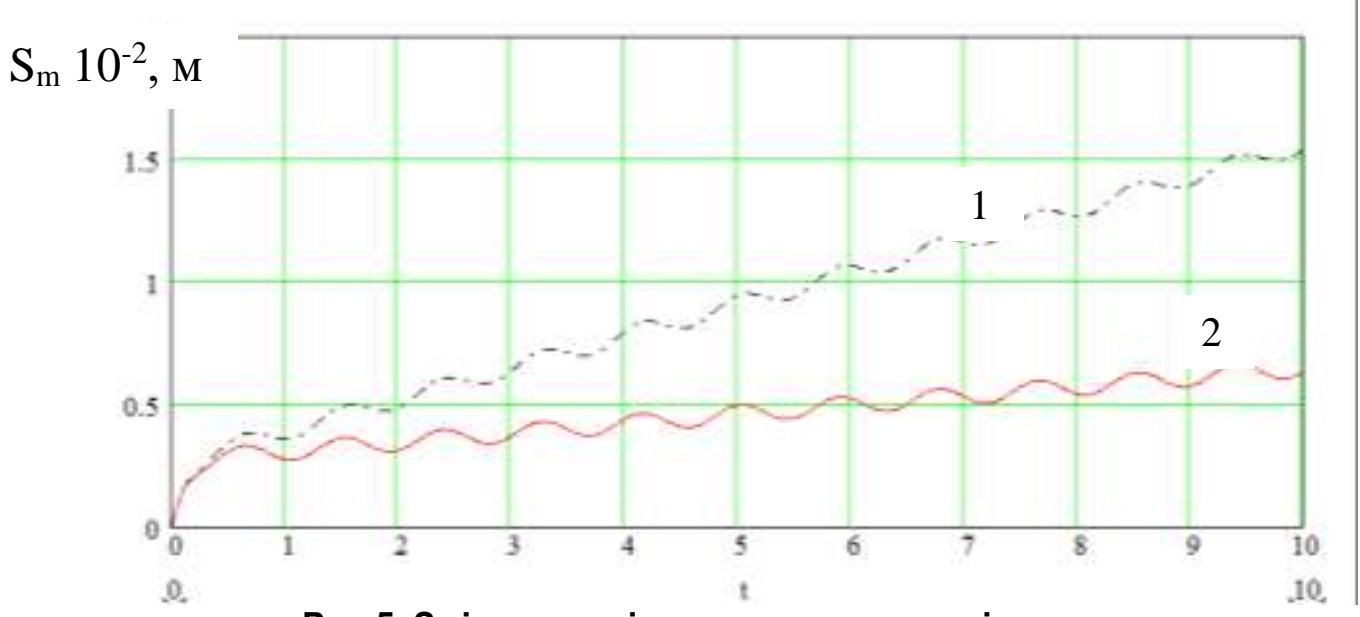

Рис.5. Зміна переміщення частки в шарі зерна при змінному (пульсуючому) потоці повітря.

1 - $m=4,2 \cdot 10^{-6}$ кг; $2-m=2,4 \cdot 10^{-6}$ кг;

Аналіз отриманих результатів показує, що використання пульсуючого повітряного потоку зі змінною швидкістю дозволяє суттєво збільшити величину розщеплення траєкторій 


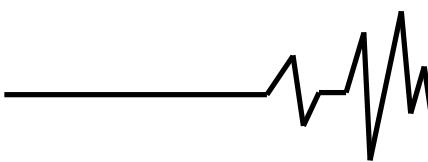

руху часток і відповідно ефективність попереднього поділу зернового матеріалу, тобто перед подачею в повітряний канал; координати «важкої» і «легкої» частинки при сходженні з поверхні лотка матимуть різні значення, що виключає їх концентрування при входженні в повітряний потік. В порівнянні 3 існуючими сепараторами які використовують горизонтальні, похилі та вертикальні пневмоканали ефективність поділу зернового матеріалу збільшується на 40-48 \%.

При сходженні частинки в повітряний канал на неї діють сили:

тяжіння $G=m g$;

\section{Вібрації в техніці} та технологіях

\section{0}

тиску

$R_{i}=K_{V} \cdot\left(V(y, t)-V_{u}\right)^{2}$;

поперечні (типу Жуковського

$F_{Ж}$ і Магнуса $F_{M}$, визначаємі за формулами $[17,18])$.

Силова взаємодія частинки 3 повітряним потоком визначається векторним рівнянням:

$$
m \frac{d \bar{v}}{d t}=\bar{G}+\bar{F}_{\mathrm{K}}+\bar{F}_{\mathrm{M}}+\bar{R}
$$

Проектуючи рівняння (11) на осі прямокутної системи координат ХОУ отримано систему рівнянь:

$$
\begin{aligned}
& \left\{\begin{array}{l}
\frac{d^{2} x}{d t^{2}}=-k_{V}\left(\vartheta(y)-\frac{d x}{d t}\right) \sqrt{\left(\frac{d x}{d t}-\vartheta(y, t)\right)^{2}+\left(\frac{d y}{d t}\right)^{2}} \mp \frac{3 \cdot\left(\mathrm{P}_{W(x)}+\mathrm{P}_{M(x))}\right.}{4 \pi r_{4}^{3} \rho} \cdot \frac{\frac{d y}{d t}}{\sqrt{\left(\frac{d x}{d t}-\vartheta(y, t)\right)^{2}+\left(\frac{d y}{d t}\right)^{2}}} \\
\frac{d^{2} y}{d t^{2}}=g-k_{V} \frac{d y}{d t} \sqrt{\left(\frac{d x}{d t}-\vartheta(y, t)\right)^{2}+\left(\frac{d y}{d t}\right)^{2}} \mp \frac{3 \cdot\left(\mathrm{P}_{W(y))}+\mathrm{P}_{M(y)}\right)}{4 \pi r_{\mu}^{3} \rho} \cdot \frac{\left(\frac{d x}{d t}-\vartheta(y)\right)}{\sqrt{\left(\frac{d x}{d t}-\vartheta(y, t)\right)^{2}+\left(\frac{d y}{d t}\right)^{2}}}
\end{array}\right. \\
& \vartheta(y, t)=A_{3}(1-\sin [\omega t]) \cdot\left(\frac{y}{H}\right)^{0,1} ; \vartheta_{\max }=A_{3}(1-\sin [\omega t]) \text {. } \\
& F_{Ж(x)}=\frac{4}{3} \pi \cdot r_{\breve{4}}^{3} \cdot \rho \cdot \frac{\vartheta_{\max }}{10 \times \mathrm{x} H^{0.1} \cdot y^{-0.1}} \cdot\left[\frac{d x}{d t}-\vartheta_{\max } \cdot\left[\frac{y}{H}\right]^{0.1}\right], \\
& F_{M(x)}=\frac{8}{3} \cdot \pi \cdot r_{\mathrm{H}}^{3} \cdot \rho \cdot \omega(t) \cdot\left[\frac{d x}{d t}-\vartheta_{\max } \cdot\left[\frac{y}{H}\right]^{0.1}\right] \text {, }
\end{aligned}
$$

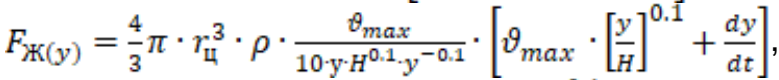

$$
\begin{aligned}
& F_{M(y)}=\frac{8}{3} \cdot \pi \cdot r_{\breve{4}}^{3} \cdot \rho \cdot \omega(t) \cdot\left[\vartheta_{\max } \cdot\left[\frac{y}{H}\right]^{0.1}+\frac{d y}{d t}\right] \text {. }
\end{aligned}
$$

$A_{3}$ - максимальна амплітуда коливань швидкості повітря.

Початкові і граничні умови в даному випадку мають вигляд:

$$
\begin{array}{r}
x(0)=0 ; y(0)=0 ; t(0)=0 ; \\
\frac{d x}{d t_{t=0}}=V_{0} \cos \alpha_{0} ; \frac{d y}{d t_{t=0}}=V_{0} \sin \alpha_{0}
\end{array}
$$

$y<0 ; F_{Ж}>0 ; F_{M}>0 ; y>0 ; F_{Ж}<0 ; F_{M}<$ $0 ;-\left(y+r_{\text {प }}\right) \leq y \leq\left(y+r_{\text {ц }}\right)$

Розв'язок системи рівнянь (12) за початкових умов отримано чисельно в середовищі MathCad-10 у вигляді залежностей $x=f(y)$ - тобто траєкторій руху частинок КЗМ (рис. 6).

3 аналізу траєкторій руху при рівномірному і нерівномірному колі швидкості повітряного потоку можна зробити висновок про доцільність підвищення ефективності поділу шляхом зміни закону розподілу швидкості потоку в каналі та використанням пульсуючого потоку

Аналізом результатів досліджень аеродинамічних схем та траєкторій поділу КЗМ в горизонтальному каналі обґрунтовано доцільність використання змінної швидкості повітряного потоку, як за висотою каналу так і в часі. При цьому розподіл швидкості повітря за висотою доцільно реалізовувати за експоненціальним законом:

$$
V_{\Pi}(\mathrm{y})=\vartheta_{0} \cdot \exp (-k \cdot x)
$$

де $\vartheta_{0}-$ швидкість повітря в центрі потоку, м/с; $k$ - емпіричний коефріцієнт. 

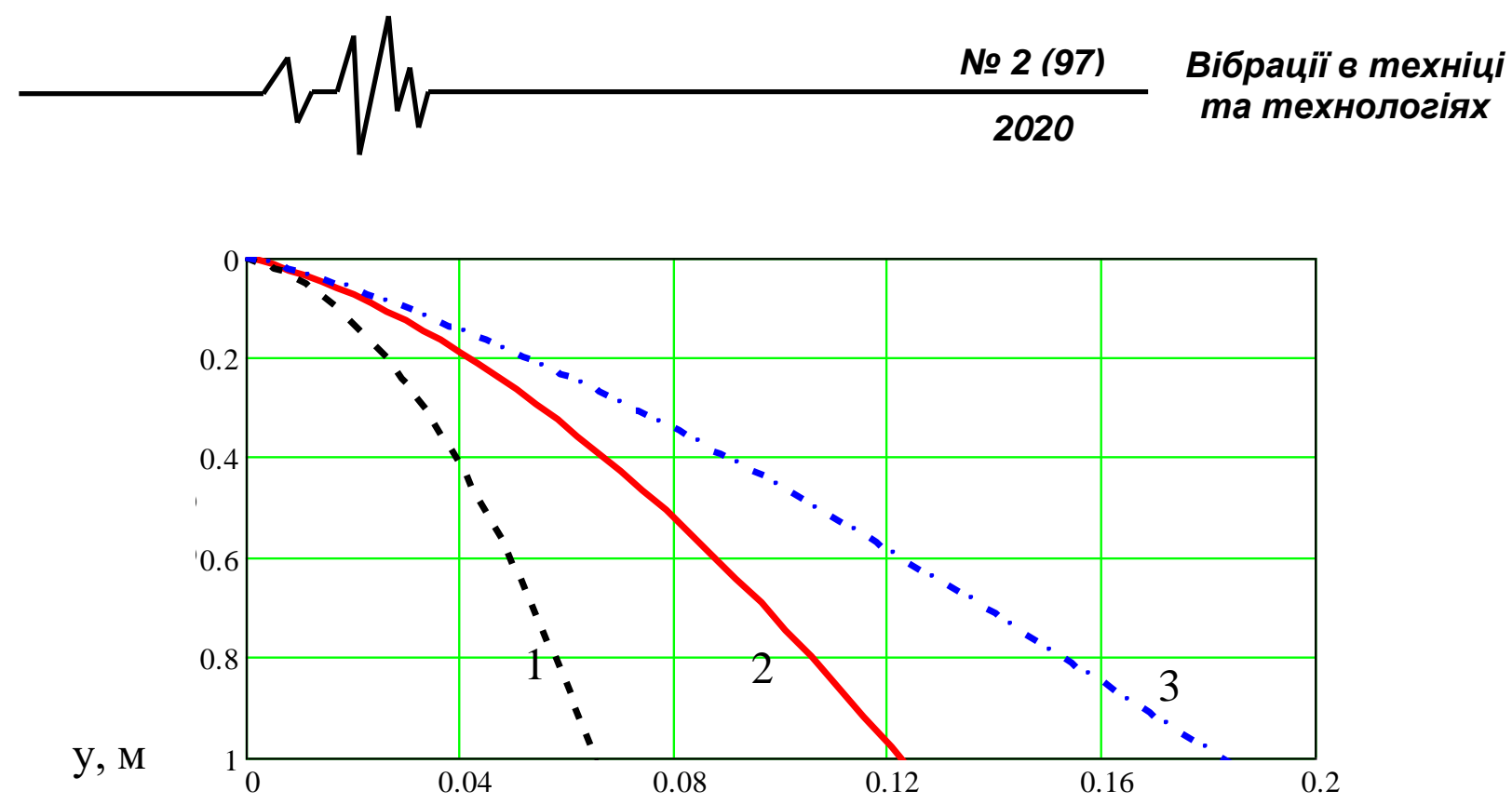

Рис.6 Траєкторії руху частинок КЗМ з прямотечієвою подачею матеріалу в повітрян

$$
V(y)=9-3,8 y 1-k_{V}=0,139 ; 2-k_{V}=0,184 ; 3-k_{V}=0,392 \text {; }
$$

Збільшення швидкості повітряного потоку в напрямку руху реалізовано лінійним законом за рахунок зміни геометрії каналу.

Одним з перспективних напрямків поділу компонентів зернового матеріалу В горизонтальному потоці є принцип тонкошарової (або струменевої) сепарації, в основу якого покладено подачу зерна (під певним кутом) в повітряний потік, швидкість якого межує із швидкістю витання основних фрракцій. В статті показано, що ефективність поділу компонентів в горизонтальному каналі можна значно підвищити застосуванням нерівномірного повітряного потоку. При цьому ефективність поділу збільшується при зміні швидкості за довжиною каналу.

\section{Висновки.}

1. В результаті аналізу проведених теоретичних досліджень встановлена можливість підвищення ефективності розділення зернових матеріалів за аеродинамічними характеристиками та питомою вагою частинок, шляхом інтенсифікації і розшарування зернового шару перед подачею в повітряний потік.

2. На основі теоретичних досліджень визначена можливість поділу частинок зернового матеріалу на фрракції за аеродинамічними властивостями при вібропневматичному завантаженні зерна в канал.

3. Використання пульсуючого повітряного потоку, як розділяючого носія та 3 урахуванням відхиляючих сил, дозволяє значно збільшити величину розщеплення траєкторій i критерій поділу зерна на фракції.

1. 4. Створені спрощені математичні моделі руху компонентів зернового матеріалу в робочих органах сепараторів з горизонтальним каналом, які дозволяють визначити раціональні режими роботи нових технічних засобів та параметри розроблюваних робочих органів.

\section{Список використаних джерел}

1. Бурков А. М.,

Сычугов М. П. Зерноочистительные машины. Конструирование, исследование, расчет и испытание. Киров: Из-во НИИСХ Северо-Востока, 2000. 258 с.

2. Дринча В. М. Исследование сепарации семян и разработка машинных технологий их подготовки. Воронеж: Издательство НПО «МОДЭК», 2006. 384 с.

3. Барский М. Д. Фракционирование порошков. М.: Недра, 1980. 327 с.

4. Ермак В. П. Концепція аеродинамічної сепарації насіння сільськогосподарських культур та засоби її реалізації: автореф. дис. ... д-ра техн. наук. Тернопіль: ТДАУ, 2009. 39 с.

5. Кошулько В. С. Тенденции развития технологических и технических средств для сепарации зерновых материалов. Хранение $и$ переработка зерна. 2014. № 2 (179). С. 22-24.

6. Степаненко С. П., Ш Швидя В. О., Попадюк I. С. Аналіз розвитку конструкцій пневмосепаруючих систем сепараторів. Механізація та електрифікація сільського господарства: загальнодержавний зб. / ННЦ «ІМЕСГ». Глеваха, 2017. Вип. № 5 (104). C. $132-142$.

7. Злочевский В. Л., Повышение технологической ефрфективности пневмофракционирования зерновых масс. Хранение и переработка зерна. 2004. № 5 (59). C. $38-40$.

8. Гортинский В. В., Демский А. Б., Борискин М. А. Процессы сепарирования на зерноперерабатывающих предприятиях. М.: Колос, 1980. 304 с.

9. Степаненко С. П. Дослідження процесу пневматичної сепарації насіння в кільцевому зигзагоподібному сепараторі. Механізація сільськогосподарського 


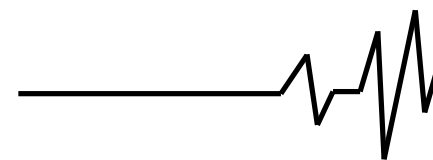

виробництва: вісник Харківського національного технічного університету сільського господарства ім. П. Василенка. Харків: ХНТУСГ, 2008. Вип. 75. Т. 1. С. 59-65.

10. Туров А. К. Пневмосепарация зерна в вертикальном канале с подготовкой в струйном плоскопараллельном потоке: автореф. дис. канд. техн. наук. Новосибирск: СИБИМЭСХ, 1984. $19 \mathrm{c}$.

11. Сабашкин В. А.

Разделение мелкосоломистого вороха с предварительной подготовкой в струйном воздушном потоке: автореф. дис. ... канд. техн. наук. Новосибирск: СИБИМЭСХ, 1988. 18 с.

12. Алієв Е.Б. Фізико-математичні моделі процесів прецизійної сепарації насіннєвого матеріалу соняшника. Запоріжжя.: Статус. 2019. $196 \mathrm{c}$.

13. Котов Б.І., Степаненко С.П. Дослідження впливу пульсуючого повітряного потоку на переміщення зерна у віброзрідженому шарі зерносоломистого вороху. Міжвідомчий тематичний науковий збірник «Механізація та електрифікація сільського господарства». 2016. Вип. №4 (103). С.38-46.

14. Паламарчук І.П., Кюрчев С.В., Кюрчева Л.М. Дослідження динаміки руху насінини при виході з живильного конуса віброаспіраційного сепаратора // Науковий вісник ТДАТУ. 2020. Вип.8. т.2. c. 139-148.

15. Кюрчев С.В. Механіко-технологічне обґрунтування післязбиральної обробки та зберігання насіння зернових і олійних культур. Автор. Дис. Докт.техн.наук. Глеваха. 2019. - 40с.

16. V.Bulgakov, S.Nikolaenko, I.Holovach, A.Boris, S.Kiurchev, Ye.Ihnatiev and J.Olt. Theory of motion of grain mixture particle in the process ofaspiration separation. Agronomy Research 18(S2), 11771188, 2020. https://doi.org/10.15159/AR.20.069.

17. Зуев, Ф.Г. Пневматическое транспортирование на зерноперерабатывающих предприятиях / Ф.Г. Зуев. - М.: Колос, 1976. - 344 с.

18. В. П. Ольшанский, С. В. Ольшанский. О траектории полета вращающейся сферической частицы. Вісник ХНТУСГ. 2009. Вип.88. с.54-61.

19. Stepanenko S. P. Research pneumatic gravity separation grain materials (Исследование воздушногравитационной сепарации зерновых материалов). Mechanization in Agriculture, conserving of the resources: International Scientific Journals of Scientific Technical Union of Mechanical Engineering "Industry 4.0". Bulgarian, 2017. Vol. 63. Issue 2. S.-54-56.

20. Моделювання технологічних процесів в типових об'єктах післязбиральної обробки і зберігання зерна (сепарація, сушіння, активне вентилювання, охолодження): монографрія / Б. І. Котов, Р. А. Калініченко, С.П.Степаненко, В. О. Швидя, В. О. Лісецький. Ніжин: Видавець ПП Лисенко М. М., 2017. 552 с.
21. Stepanenko S.P., Kotov B.I. Pneumonitis fractionation of grain materials in air streams of variable structure. An International Quarterly Journal on Motorization, Vehicle Operation, Energy Efficiency and Mechanical Engineering. Lublin-Rzeszow. TEKA.2018. Vol. 18. No 2. p. 69-74.

22. Stepanenko S.P., Kotov B.I. Theoretical research of separation process grain mixtures. An International Quarterly Journal on Motorization, Vehicle Operation, Energy Efficiency and Mechanical Engineering. Lublin-Rzeszow. TEKA.2018. Vol. 18. No 3, p. 49-54.

23. Stepanenko S.P., Kotov B.I. Theoretical research of separation process grain mixtures. Machinery \& Energetics. Journal of Rural Production Research. 2019, Vol. 10, N.4. pp.137-143. DOI:10.31548/machenergy.2019.04.147-153.

\section{Список джерел у транслітерації}

1. Burkov A. M., Sychugov M. P. Zernoochistitel'nyye mashiny. Konstruirovaniye, issledovaniye, raschet $\mathrm{i}$ ispytaniye. Kirov: Iz-vo NIISKH Severo-Vostoka, 2000. $258 \mathrm{~s}$.

2. Drincha V. M. Issledovaniye separatsii semyan i razrabotka mashinnykh tekhnologiy ikh podgotovki. Voronezh: Izdatel'stvo NPO «MODEK», 2006. $384 \mathrm{~s}$

3. Barskiy M. D. Fraktsionirovaniye poroshkov. M.: Nedra, 1980. $327 \mathrm{~s}$.

4. Yermak V. P. Kontseptsíya ayerodinamíchnoî separatsiî nasínnya sil's'kogospodars'kikh kul'tur ta zasobi iî realízatsiî: avtoref. dis. ... d-ra tekhn. nauk. Ternopíl': TDAU, 2009. $39 \mathrm{~s}$

5. Koshul'ko V. S. Tendentsii razvitiya tekhnologicheskikh i tekhnicheskikh sredstv dlya separatsii zernovykh materialov. Khraneniye i pererabotka zerna. 2014. № 2 (179). S. 22-24.

6. Stepanenko S. P., Shvidya V. O., Popadyuk Í. S. Analíz rozvitku konstruktsíy pnevmoseparuyuchikh sistem separatorív. Mekhanízatsíya ta yelektrifíkatsíya síl's'kogo gospodarstva: zagal'noderzhavniy zb. / NNTS «ÍMESG». Glevakha, 2017. Vip. № 5 (104). S. 132142.

7. Zlochevskiy V. L., Terekhova O. N. Povysheniye tekhnologicheskoy yeffektivnosti pnevmofraktsionirovaniya zernovykh mass. Khraneniye i pererabotka zerna. 2004. № 5 (59). S. $38-40$.

8. Gortinskiy V. V., Demskiy A. B., Boriskin M. A. Protsessy separirovaniya na zernopererabatyvayushchikh predpriyatiyakh. M.: Kolos, $1980.304 \mathrm{~s}$

9. Stepanenko S. P. Doslídzhennya protsesu pnevmatichnoî separatsií nasínnya $\mathrm{V}$ kil'tsevomu zigzagopodíbnomu separatorí. Mekhanízatsíya sil's'kogospodars'kogo virobnitstva: vísnik Kharkívs'kogo natsíonal'nogo tekhníchnogo 
$\longrightarrow$

uníversitetu síl's'kogo gospodarstva ím. P. Vasilenka. Kharkív: KHNTUSG, 2008. Vip. 75. T. 1. S. 59-65.

10. Turov A. K. Pnevmoseparatsiya zerna v vertikal'nom kanale $\mathrm{s}$ podgotovkoy $\mathrm{v}$ struynom ploskoparallel'nom potoke: avtoref. dis. ... kand. tekhn. nauk. Novosibirsk: SIBIMESKH, 1984. 19 s.

11. Sabashkin V. A. Razdeleniye melkosolomistogo vorokha s predvaritel'noy podgotovkoy v struynom vozdushnom potoke: avtoref. dis. ... kand. tekhn. nauk. Novosibirsk: SIBIMESKH, 1988. $18 \mathrm{~s}$.

12. Aliêv Ye.B. Fíziko-matematichní modelí protsesív pretsizíynoî separatsií nasínnêvogo materíalu sonyashnika. Zaporízhzhya.: Status. 2019. $-196 \mathrm{~s}$.

13. Kotov B.Í., Stepanenko S.P. Doslídzhennya vplivu pul'suyuchogo povítryanogo potoku na peremíshchennya zerna u víbrozrídzhenomu sharí zernosolomistogo vorokhu. Mízhvídomchiy tematichniy naukoviy zbírnik «Mekhanízatsíya ta yelektrifíkatsíya síl's'kogo gospodarstva». 2016. Vip. №4 (103). S.38-46.

14. Palamarchuk Í.P., Kyurchev S.V., Kyurcheva L.M. Doslídzhennya dinamíki rukhu nasínini pri vikhodí z zhivil'nogo konusa víbroaspíratsíynogo separatora // Naukoviy vísnik TDATU. 2020. Vip.8. t.2. s. 139-148.

15. Kyurchev S.V. Mekhaníko-tekhnologíchne obg̀runtuvannya píslyazbiral'noî obrobki ta zberígannya nasínnya zernovikh í olíynikh kul'tur. Avtor. Dis. Dokt.tekhn.nauk. Glevakha. 2019. - 40s.

16. V.Bulgakov, S.Nikolaenko, I.Holovach, A.Boris, S.Kiurchev, Ye.Ihnatiev and J.Olt. Theory of motion of grain mixture particle in the process ofaspiration separation. Agronomy Research 18(S2), 11771188, 2020. https://doi.org/10.15159/AR.20.069.

17.Zuyev, F.G. Pnevmaticheskoye transportirovaniye na zernopererabatyvayushchikh predpriyatiyakh / F.G. Zuyev. - M.: Kolos, 1976. - 344 s.

18. V. P. Ol'shanskiy, S. V. Ol'shanskiy. O trayektorii poleta vrashchayushcheysya sfericheskoy chastitsy. Vísnik KHNTUSG. 2009. Vip.88. s.54-61.

19. Stepanenko S. P. Research pneumatic gravity separation grain materials (Issledovaniye vozdushnogravitatsionnoy separatsii zernovykh materialov). Mechanization in Agriculture, conserving of the resources: International Scientific Journals of Scientific Technical Union of Mechanical Engineering "Industry 4.0". Bulgarian, 2017. Vol. 63. Issue 2. S. $-54-56$.

20. Modelyuvannya tekhnologíchnikh protsesív v tipovikh ob'êktakh píslyazbiral'noï obrobki í zberígannya zerna (separatsíya, sushínnya, aktivne ventilyuvannya, okholodzhennya): monografíya / B. Í. Kotov, R. A. Kalíníchenko, S. P. Stepanenko, V. O. Shvidya, V. O. Lísets'kiy. Nízhin: Vidavets' PP Lisenko M. M., 2017. $552 \mathrm{~s}$.

21. Stepanenko S.P., Kotov B.I. Pneumonitis fractionation of grain materials in air streams of variable structure. An International Quarterly Journal on Motorization, Vehicle Operation, Energy Efficiency and Mechanical Engineering. Lublin-Rzeszow. TEKA.2018. Vol. 18. No 2. p. 69-74.

22. Stepanenko S.P., Kotov B.I. Theoretical research of separation process grain mixtures. An International Quarterly Journal on Motorization, Vehicle Operation, Energy Efficiency and Mechanical Engineering. Lublin-Rzeszow. TEKA.2018. Vol. 18. No 3, p. 49-54.

23. Stepanenko S.P., Kotov B.I. Theoretical research of separation process grain mixtures. Machinery \& Energetics. Journal of Rural Production Research. 2019, Vol. 10, N.4. pp.137-143. DOI:10.31548/machenergy.2019.04.147-153.

\section{MATHEMATICAL MODELING OF PROCESSES OF SEPARATION OF COMPONENTS OF GRAIN MATERIAL IN THE COMBINED VIBRATION-AIR SEPARATOR}

Development of a mathematical model and calculated analytical dependencies for determining the trajectories and parameters of grain movement in a vibro-fluidized layer of grain material components under the action of a pulsating air flow.

They are based on the methods of deterministic mathematical modeling and theoretical mechanics based on the equations of motion of a material point at a variable air flow speed and the action of a pulsating air flow. Theoretical studies were carried out using the methods of mathematical analysis and modeling. The research results were processed using elements of the theory of probability and mathematical statistics using software packages; to determine the rational parameters of the process, the method of statistical experiment planning was used.

A mathematical description of the motion of the grain material particles in a combined vibration-air separator under the action of a pulsating air flow of variable speed is given. The trajectories of motion of particles with different sizes are obtained.

The obtained equation of motion of a particle under the influence of a pulsating air flow makes it possible to determine the dependence of the speed of movement of the material in a vibro-fluidized layer of grain material on a number of factors: the geometric parameters of the sieve-free sieve, the feed angle of the material, the initial kinematic mode of the material, the index of the kinematic mode of the sieve-free sieve, as well as the coefficient of windage of the grain.

On the basis of theoretical studies, the possibility of separating particles of grain material into fractions according to aerodynamic properties with vibropneumatic loading of grain into the channel has been determined. The use of a pulsating air flow as a separating carrier, and taking into account the deflecting forces, made it possible to significantly increase the splitting of the trajectories and the criterion for dividing the grain into fractions. 


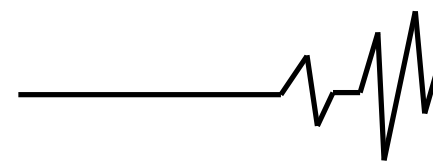

Key words: vibration-air separator, air flow, variable air speed, trajectory, drag force, pulsating air flow, windage coefficient.

\section{МАТЕМАТИЧЕСКОЕ МОДЕЛИРОВАНИЕ ПРОЦЕССОВ РАЗДЕЛЕНИЯ КОМПОНЕНТОВ ЗЕРНОВОГО МАТЕРИАЛА В КОМБИНИРОВАННОМ ВИБРАЦИОННО- ВОЗДУШНОМ СЕПАРАТОРЕ}

Разработка математической модели и расчетных аналитических зависимостей для определения траекторий и параметров перемещения зерна в вибропсевдоожиженном слое компонентов зернового материала (КЗМ) при действии пульсирующего воздушного потока.

Базируются на методах
математического
детерминированного математического моделирования и теоретической механики на базе уравнений движения материальной точки при переменной скорости воздушного потока и действия пульсирующего воздушного потока. Теоретические исследования проведены с использованием методов математического анализа и моделирования. Результаты исследований обработаны с применением элементов теории вероятности и математической статистики с использованием пакетов прикладных программ, для определения рациональных параметров процесса применялась методика статистического планирования эксперимента.
№ 2 (97)

2020

Приведено математическое описание движения частиц КЗМ в комбинированном вибрационно-воздушном сепараторе при действии пульсирующего потока воздуха переменной скорости. Получены траектории движения частиц с различным размером.

Полученное уравнение движения частицы при воздействии пульсирующего потока воздуха позволяет определить зависимость скорости движения материала в вибропневмоожиженном слое зернового материала от ряда фракторов: геометрических параметров безпровального решета, угла подачи материала, начального кинематического режима материала, показателя кинематического режима безпровального решета, а также коэффициента парусности зерновки.

На основе теоретических исследований определена возможность разделения частиц зернового материала на фрракции по аэродинамическим свойствам при вибропневматической загрузке зерна в канал. Использование пульсирующего воздушного потока, как разделяющего носителя, и с учетом отклоняющих сил, позволило значительно увеличить величину расщепления траекторий и критерий разделения зерна на фракции.

Ключевые слова: вибрационновоздушный сепаратор, воздушный поток, переменная скорость воздуха, траектория, сила сопротивления, пульсирующий поток воздуха, коэфрфициент парусности.

\section{Відомості про авторів}

Степаненко Сергій Петрович - кандидат технічних наук, старший науковий співробітник, Завідувач відділу перспективних технологій і технічних засобів для збирання, обробки та зберігання врожаю зернових і олійних культур Національного наукового центру "Інститут механізації та електриффікації сільського господарства" (вул. Вокзальна, 11, смт. Глеваха, Васильківський район, Київська область, Україна e-mail: Stepsnenko s@ukr.net).

Степаненко Сергей Петрович - кандидат технических наук, старший научный сотрудник, заведующий отделом перспективных технологий и технических средств для сбора, обработки и хранения урожая зерновых и масличных культур Национального научного центра "Институт механизации и электрификации сельского хозяйства" (ул. Вокзальная, 11, пг. Глеваха, Васильковский район, Киевская область, Украина e-mail: Stepsnenko s@ukr.net).

Stepanenko Sergey - Candidate of Technical Sciences, Senior Researcher, Head of the Department of Advanced Technologies and Technical Means for Harvesting, Processing and Storage of Grain and Oilseeds Crops of the National Research Center "Institute of Mechanization and Electrification of Agriculture" (11 Vokzalnaya St., town. Glevakha, Vasilkovsky district, Kiev region, Ukraine e-mail: Stepsnenko_s@ukr.net). Котов Борис Іванович- доктор технічних наук, професор кафедри агроінженерії і системотехніки Подільського державного аграрно-технічного університету (вул. Шевченка, 13, м. Кам'янець-Подільський, Хмельницька обл., Україна, 32316).

Котов Борис Иванович- доктор технических наук, профессор кафедры Агроинженерия и системотехники Подольского государственного аграрно-технического университета (ул. Шевченко, 13, г. Каменец-Подольский, Хмельницкая обл., Украина, 32316).

Kotov Borys - Doctor of Technical Sciences, Professor of the Department of Agroengineering and Systems Engineering of Podolsk State Agrarian and Technical University (13 Shevchenko St., Kamyanets-Podilsky, Khmelnytsky Region, Ukraine, 32316). 